\title{
Nesâî’nin (ö. 303/915) Şiîlikle İthamı
}

\author{
Dr. Öğr. Üyesi Veli ABA*
}

Atıf / @- Aba, V. (2018). Nesâî'nin (ö. 303/915) Şiîlikle İthamı, Çukurova Üniversitesi Ilahiyat Fakültesi Dergisi, 18 (1), 167-191.

Öz- Hadisler, raviler ve telif edilen eserler çeşitli açılardan belli kriterlere tabii tutularak uzmanlarınca incelenirler. Bu inceleme neticesinde ortaya çıkan sonuca göre belli bir hüküm verilir. Dolayısıyla tarihi süreçte bir ravi hakkında değişik görüşler ileri sürülmüş olabilir. Bu görüşlerin gerçek olup olmadıkları ise kimi zaman tam olarak ortaya çıkarılamaz ve bir ravi hak etmediği bir suçlama ile karşı karşıya kalabilir. Cerh-ta'dîl kriterleri bağlamında bazan bir ravinin eleştirilmesiyle ilgili farklı maddelerin ileri sürülmüş olduğu görülür. Bunlardan biri de ravinin Şiîlikle suçlanmasıdır. Hadis bilim dalına başta Sünen olmak üzere birçok kıymetli eser kazandıran Nesâî de Şiîlik suçlamasına maruz kalmış muhaddislerden biridir. Kaynaklarda Nesâi hakkında ileri sürülen bu tür ithamlar yer almış olsa da bunlar sağlam delillere dayanmamaktadır. Fakat yine de söz konusu ithamlar kendisini tartışma konusu yapmış, ilerleyen zaman diliminde bu tür ithamlar onun gündeme gelmesine neden olmuştur. Tabiatıyla hadiste otorite olan Nesâînin tenkit sebebi olan bir vasıfla anılması dikkatleri üzerine çekmiştir. Bu çalışmada söz konusu iddiaların dayandırılığı bilgilerin sıhhati ve ileri sürülen delillerin geçerliliği incelenmiş böylece Nesâînin Şiîlikle ithamının ne derece doğru olduğu ortaya konmaya çalışılmıştır. Illeri sürülen bilgi ve deliller bütüncül bir bakış açısıyla değerlendirildiğinde as/ında Nesâînin takip ettiği metotla iki grup arasında devam eden mücadelelere karşı bilinçli bir denge politikası ortaya koymaya çalıştığı anlaşılmaktadır.

Anahtar sözcükler- Nesâî, Şiîlik ithamı (teşeyyu), Cerh, Sünnî, Râfîzî, Hz. Ali, Muâviye

\section{$\S \S \S$}

Makalenin gelişi: 13.05.2018; Yayına kabul tarihi: 12.06.2018

* KSÜ Üniversitesi İlahiyat Fakültesi Hadis Anabilim Dalı, e-posta: vaba75@hotmail.com (ORCID: 0000-0003-4558-038X) 


\section{Giriş}

İslam kültür tarihinde muhaddislerin önemli bir yeri vardır. Kur'ân ayetlerinin sübutunun katîliği çeşitli polemiklere set çekmiş olsa da aynı durumun hadisler için geçerli olduğu söylenemez. İslâm'ın ikinci kaynağı olarak kabul görmesine rağmen hadisler ve hadis kitapları ile muhaddisler üzerinde tarihi süreçte bazı tartışmalar yaşanagelmiştir. Kimi zaman şahıs, kimi zaman eser kimi zaman da görüş ve fikirler ile yöntemler ayrıca diğer birçok farklı konularda devam edip gelen bu tartışmalar hadis bilim dalında belli bir süre sonra özel bir alan meydana getirmiş artık her bir şahıs hakkında bununla ilgili ricâl ve tabakat kitapları meydana getirilmiştir. Şüphesiz ki şahıslar üzerinde yapılan tartışmaların boyutları yer yer değişik ithamlara kadar dayanmıştır. Hadis bilim dalında cerh tabirleriyle ifade edilen bu suçlamalardan biri de Şiîlik propagandasıyla ithamdır. Sadece gerçek manada Şiîlik propagandası yapanların değil bugüne kadar bize ulaşmış temel hadis kaynaklarında Ehl-i Sünnet çizgisinde bulunan bazı muhaddislerin de bu suçlamaya maruz kaldığı görülmektedir.

Tarihi süreçte birçok fırka, mezhep ve değişik dinî grupların genelde kendilerine yakın gördükleri şahıs, eser ve fikirlere meylettikleri bilinen bir husustur. Tıpkı bunun gibi hem Şîa hem Ehl-i Sünnet muhaddisleri de râvi, eser ve fikirler bakımından kendilerine yakın çizgide bulunanlara itibar etmişlerdir. Fakat Şîa'nın bazı kollarında sonraki süreçte mezhep ve fırkaya aşırı bağlılık, propagandist düşünceyle hareket tarzı hadis ilmine yaklaşım tarzını değiştirmiş, bu ilim dalı objektif değerlendirme kriterinden çok Şâa'daki söz konusu bazı fırka ve mezhebin savunma ve propaganda aracı olarak görülmeye başlanmıştır. Tabii ki bu tür bir anlayış doğal olarak kendilerine yakın şahıs, fırka, mezhep vb. grup mensuplarına karşı mütesâhil karşı tarafa ise müteşeddit olmayı da beraberinde getirmiştir. Bu minvalde yapılan değerlendirme ve tenkitler ise nesnel bir uygulama olarak kabul görmemiştir.

Nitekim Kütüb-i Sitte'den biri olan es-Sünen'in müellifi, muhaddis enNesâî (ö. 303/915) de zikredilen süreçte Şiîlikle itham edilenlerden biri olmuştur. Bu araştırmamızda Nesâî hakkında kaynaklarda yer alan bu ithamların aslı ve değerini aynı zamanda bunların nasıl anlaşılması gerektiğini cevaplamaya çalışacağız.

Yukarıda da kısmen değinildiği gibi İslam tarihinde birçok şahsiyetin/âlimin Şiîlik, Râfizîlik gibi marjinal olarak görülen ve mezhebî aidiyetleri 
doğrultusunda hareket eden gruplarla ilişkilendirildikleri kaynaklarda yer almıştır. Aynı şekilde bazen hayatı, fikirleri ve yazdığı eserleriyle Ehl-i Sünnet çizgisinin en önemli savunucuları olarak da kabul görmüş muhaddislerin bu tür ithamlarla karşı karşıya kaldıkları olmuştur. Bu şekilde suçlanan âlimlerden bazıları farklı araştırmalarla tek tek/şahıs olarak incelense de bunların sayısı hayli düşük kalmıştır. Ayrıca şu ana kadar bu tür şahısların hepsini içine alan bir araştırmanın yapıldığını tespit edemedik. Hâlbuki tarihi süreçte Şîilikle suçlanan şahsiyetlerin/âlimlerin ilgi alanlarına, mezhebî özelliklerine, yaşadıkları coğrafya ve daha farklı birçok vasıflarına göre bir araya getirilmeleri bu konuda yapılacak araştırmalar için büyük bir imkân sunmuş olacaktır. Ülkemizde hadis ve hadis usulü esas alınarak Şîa'ya yönelik yapılan bazı çalışmalar mevcuttur. ${ }^{1}$ Şîa'nın hadise bakışını ve hadis ilmi açısından konumunu be-

Direkt konumuzla ilgili olmasa da bu alanda yapılan çalışmalardan bazıları: Sofuoğlu, M. Cemal, Şîa'nın Hadis Anlayışı, Doktora Tezi, Ankara Üniversitesi İlahiyat Fakültesi, Ankara, 1977; a.mlf., Hadis Tenkidi Yönünden el-Kâfî Üzerine Bir Deneme, Ankara Üniversitesi İlahiyat Fakültesi Yayınları, Ankara, 1982; Çolak, Ahmet, Şia Hadis Alma Usulünde IIlk Raviler, Basılmamış Yüksek Lisans Tezi, Erzurum Atatürk Üniversitesi Sosyal Bilimler Enstitüsü, Erzurum, 1993; Kutlu, Cahit, Şîa'nın Hadis Vaz'ındaki Rolü, Yüksek Lisans Tezi, Ankara Üniversitesi Sosyal Bilimler Enstitüsü, Ankara, 1995; Uyar, Mazlum, İmâmiyye Şîası'nda Ahbârîlik, Doktora Tezi, Dokuz Eylül Üniversitesi Sosyal Bilimler Enstitüsü, İzmir, 1996 (Bu çalışma Imâmiyye Şîası'nda Düşünce Ekolleri-Ahbârîlik" adıyla yayımlanmıştır (İstanbul, 2000); Ateş, Ali Osman, Ehl-i Sünnet ve Şîa'nın Delil Aldığı Bazı Hadisler, Beyan Yayınları, İstanbul, 1996; Kandemir, M. Yaşar, "Hadis/Şîa ve Hadîs", DiA, XV, 38-40; Ünalan, Abdullah, Ehl-i Sünnet ve Şîa'nın Imamette Dayandığı Hadisler, Doktora Tezi, Harran Üniversitesi Sosyal Bilimler Enstitüsü, Şanlıurfa, 1998; Tokpınar, Mirza, "Abdurrezzak b. Hemmâm'ın Şiilikle İtham Edilmesi Üzerine Bir İnceleme (I-)”, Dini Araştırmalar, 2001, IV, sy 9, s. 77-92; Tokpınar, Mirza, "Abdurrezzak b. Hemmâm'ın Şiilikle İtham Edilmesi Üzerine Bir İnceleme (II-)", Dini Araştırmalar, 2001, IV, sy 10, s. 71-88; Oğur, Necmettin, Şîa'da Ricâl IIIminin Gelişimi ve Bu Alanda Yapılan Çalışmalar, Yüksek Lisans Tezi, Marmara Üniversitesi Sosyal Bilimler Enstitüsü, İstanbul, 2002; Büyükkara, Mehmet Ali, "İmâmiyye Şia'sının Hadis Usûlünde Mezhebi Bozuk Raviler (I-)”, İslâmî Araştırmalar Dergisi, 2004, XVII, sy 3, s. 201-215; Büyükkara, Mehmet Ali, "İmâmiyye Şia'sının Hadis Usûlünde Mezhebi Bozuk Raviler (II-)", İslâmî Araştırmalar Dergisi, 2004, XVII, sy 4, s. 354-368; Demirci, Kadir, Zeydiyye'nin Hadis Anlayışı, Basılmamış Doktora Tezi, Ankara Üniversitesi Sosyal Bilimler Enstitüsü, Ankara, 2005; Evgin, Abdulkadir, "Caferî İnanç Sisteminde Hadîs Anlayışı", Din Bilimleri Akademik Dergisi, 2004, IV, sy. 1, s. 117-147; Evgin, Abdulkadir, "Hanefî ve Ca'ferîlerin Hadis Anlayışlarına Karşılaştırmalı Bir Bakış", Imâm-ı Azam Ebû Hanîfe ve Düşünce Sistemi (Sempozyum Tebliğ ve Müzakereleri), I-II, Bursa, 2005, I, s. 435-439; Yavuz, Adil, "Kisâ Hadisi Rivâyetleri ve Ehl-i Beyt Kimliği”, Selçuk Üniversitesi Illahiyat Fakültesi Dergisi, 2005, sy. 19, s. 153-177; Ünalan, Abdullah, Şia'da Hadis Usûlü, İşrak Yayınları, İstanbul, 2008; Karahan, Abdullah, "Şîa'nın Dört Muteber Ricâl Kitabı", Marife, yıl. 8, sayı. 3, kış 2008, ss. 309-329; Eren, Mehmet, Şîa'da Hadis Ricâli İmi Kaynakları ve Konuları, Konya, 2010; Kutluay, İbrahim, Imâmiyye Şîası'na Göre Cerh ve Ta'dîl, Rağbey Yayınları, İstanbul, 2012; Aydınlı, Abdullah, "Şîa'da Hadis", Hadîs Yazıları, İstanbul, 2014, s. 223-234; Demirel, Serdar, Ehl-i Sünnet İle İmâmiye Şiası Arası Karşılaştırmalı Hadis İlimleri, Karınca Polen Yayınları, İstanbul, 2014; Kutluay, İbrahim, "İmâmiyye Şîası'na Göre Haber-i Vâhidin Hücciyeti Problemi-Şeyhü't-Tâife et-Tûsî Özelinde-”, Marife, 2014, XIV, sy.2, s. 63-84; Yıldırım, Enbiya, "el-Hâkim en-Neysâbûrî'nin Şiîlikle İtham Edilmesi”, Ankara Üniversitesi İlahiyat Fakültesi Dergisi, 57:1 (2016), ss.57-84; Kuzudişli, Bekir, Şîa ve Hadis, Klasik, İstanbul, 2017. 
lirleyebilmek açısından bu araştırmaların faydası tartışı Imaz olmakla birlikte konumuzla direkt ilgisi olan çalışmaların ise sayı bakımından yeterli olduğu söylenemez. Dolayısıyla bu alanda daha birçok araştırma yapılmasına intiyaç vardır. $^{2}$

Bu çalışmanın amaçlarından biri de Nesâî'nin şahsında zikredilen eksikliği tamamlamaktır. Daha önce Enbiya Yıldırım tarafından Hâkim enNeysâbûrî'nin Şiîlikle itham edilmesine dair yapılmış çalışmanın³ devamı niteliğinde de değerlendirilebilecek bu çalışmayla bütüne ulaştıracak parçalardan birinin tamamlanması hedeflenmektedir. Tabii ki, daha önce de zikredildiği gibi bu tür çalışmalara katkı olması bakımından hala çalışımamış şahıs ve fikirlerin de daha sonra çalışılarak İslam kültür tarihinde Şîilikle suçlanan şahısların/âlimlerin tek tek ortaya çıkarılmış olmasının bu konuda karanlık kalan ya da yanlış nakledilmiş olan birçok bilgileri de ortaya çıkaracağı kanaatindeyiz

Bunlara ilaveten çalışmanın yöntemi ve kaynak kullanımı ile ilgili bazı prensipler esas alınmıştır. Nesâînnin Şîilikle ithamında göz önünde bulundurulması gereken en önemli delillerden birinin de yazdığı eserler olduğu kanaatindeyiz. Çünkü bu eserlerde Şîilikle itham edilenler için kayda değer bir argüman olarak görülebilecek Hz. Ali'nin efdâliyyeti, Muâviye'nin ithamı, Ehl-i Beyt'e bakış, SünnîlikEhl-i Sünnet ve Şîa arasındaki siyasi olaylara yaklaşım tarzı gibi emâreler bulunabilir. ${ }^{4}$ Dolayısıyla çalışmada başta Nesâî'nin Fedâil konusunda yazılmış ilk müstakil eserlerden olan Fedâilü's-Sahabe'si ile Hz. Ali ve ailesinin faziletlerine dair rivâyetleri intiva eden el-Hasâis'i temel kaynak olarak dikkate alınmıştır. Bunun yanında hem Ehl-i Sünnet hem de Şîa'nın itibar ettiği ricâl edebiyatı ayrı ayrı taranarak Nesâî hakkında ayrıntılı bilgilere ulaşılmaya çalışılmıştır. Elbette ki sadece yukarıda zikredilen eserlerle yetinilmeyip müellifin diğer eserleri de gözden geçirilerek onun Şîilikle ithamına delil teşkil edebilecek bilgiye de ulaşılmaya çalışımıştır.

2 Bu iddialar hakkında geniş bilgi için bkz. Karahan, Abdullah, "Şîa'nın Dört Muteber Ricâl Kitabı", Marife, yıl. 8, sayı. 3, kış 2008, s. 310.

3 Bkz. Yıldırım, Enbiya, "el-Hâkim en-Neysâbûrî̀nin Şiîlikle İtham Edilmesi", Ankara Üniversitesi Illahiyat Fakültesi Dergisi, 57:1 (2016), ss.57-84.

4 Bu konuda Ehl-i Sünnet ile Şia arasında gerçekleşen tartışmalar için bkz. Önal, Recep, Ebü’Berekât en-Nesefî ve Kelamî Polemikleri, Emin Yay., Bursa, 2017, s. 366-374. 


\section{Nesâî'nin Kısa Biyografisi}

Hayatını baştan sona ayrıntılarıyla anlatmaktan ziyade Nesâînin ilmi, itikadı, mezhebi ve eserleri hakkında gerekli bilgilerle yetinilmesi araştırmanın hedef ve kapsamı açısından daha uygun olacağından bu kısımda sadece bazı genel malumatlara değinilecektir.

215/830 yılında Horasan bölgesindeki Nesâ'da doğduğu belirtilen Nesâî'nin tam adı Ebû Abdurrahmân Ahmed b. Şuayb b. Alî en Nesâî'dir. ${ }^{5}$ Fakat bazı kaynaklarda isminin Ahmed b. Ali b. Şuayb şeklinde de kaydedildiği görülmektedir. Küçük yaşta Kur'ân ve hadis derslerine başlayan Nesâî 230/844 yılında kendisinden en çok faydalandığı hocası Kuteybe b. Saîd'den hadis okumak üzere Belh yakınındaki Bağlan köyüne gitti ve onun yanında on dört ay kaldı. Ayrıca İbn Râhûye, Ebu'l-Hasan İbn Ebî Şeybe, Ahmed b. Hanbel, Ahmed b. Menî, Ali b. Hucr, Hişâm b. Ammâr, Duhaym, İbrahim b. Saîd el- Cevherî, Fellâs, Muhammed b. Beşşâr el-Bündâr, İbn Müsennâ, Ebû-Züra er-Râzî, Ebû Hâtim er-Râzî, Bezzâr, Ebu'l-İshâk el-Cüzcânî, Ebû Ya'lâ elMevsılî gibi muhaddisler de onun hocaları arasındadır. Hadis tahsili için Horasan, Hicaz, Mısır, Irak, el-Cezîre, Suriye gibi ilim merkezlerine seyahat etti ve daha sonra Mısır'a yerleşti. Ayrıca Ebû Dâvûd es-Sicistânî ve Abdullah b. Ahmed b. Hanbel gibi akranlarından da hadis rivâyet eden Nesâî'den oğlu Abdülkerim ile Kâsım b. Sâbit, Ebû Bişr ed-Dûlâbî, Tahâvî, Ebû Avâne elİsferâyînî, Ukaylî, Ebû Ali en-Nîsâbûrî, İbn Hibbân, Taberânî, İbn Adî gibi âlimler hadis rivâyet etti. ${ }^{6}$ Nesâî'nin burada ve diğer kaynaklarda zikredilen hocaları ve öğrencilerine bakıldığında onun üzerinde etkili olup kendisinin teşeyyu ile suçlanmasına delil teşkil edecek şekilde Şiîliğiyle tebârüz etmiş bir şahsın bulunmadığı görülecektir.

5 İbnu'l-Cevzî, Cemalüddîn Ebu'l-Ferec Abdurrahman b. Ali b. Muhammed el-Cevzî, elMuntazam fî târîhi'l-umemi ve'l-mulûk, (I-XIX), thk. Muhammed Abdulkadir Atâ/Mustafa Abdulkadir Atâ, Dâru'l-kütübi'l-ilmiyye, Beyrût, 1992, XIII, 155, 156; Zehebî, Şemsüddîn Ebû Abdullah Muhammed b. Ahmed b. Osman b. Kaymâz, el-iber fî haberi men gaber, (I-IV), thk. Ebû Hâcir Muhammed es-Saîd, Dâru'l-kütübi'l-ilmiyye, Beyrut, ts., I, 444; Siyeru a'lâmi'nnübelâ, (I-XL), Dâru'l-hadîs, Kahire, 2006, XI, 85; İbnu'l-İmâd, Ebü'l-Felâh Abdülhay b. Ahmed b. Muhammed es-Sâlihî el-Hanbelî, Şezerâtu'z-zeheb fî ahbâri men zeheb, (I-XI), thk. Mahmûd el-Arnaûd, Dâru İbn Kesîr, Dımeşk/Beyrut, 1986, IV, 18.

6 Ayrıntılı bilgi için bkz. İbnu'l-Cevzî, Ebü’l-Ferec Cemâlüddîn Abdurrahmân b. Alî b. Muhammed el-Bağdâdî, el-Muntazam fî târîhi'l-umemi ve'l-mulûk, (I-XIX), thk. Muhammed Abdulkadir Atâ/Mustafa Abdulkadir Atâ, Dâru'l-kütübi'l-ilmiyye, Beyrût, 1992, XIII, 155, 156; Zehebî, el-iber, I, 444; a.mlf., Siyeru a'lâmi'n-nübelâ, (I-XL), Dâru'l-hadîs, Kahire, 2006, XI, 81-85; İ̉bnu'l-İmâd, IV, 18; Kandemir, M. Yaşar, "Nesâî", DIA, XXII, 563. Bu bağlamada bkz. Robson, James, Sünen-i İbn Mâce'nin (Nüshalarının) Rivâyeti, çev. Musa Erkaya, Dinî Araştırmalar, 2005, cilt: VIII, sayı: 23, s. 287-298. 
13 Safer 303'te (25 Ağustos 915) Filistin'deki Remle'de vefat ettiği söylenen Nesâînin Kudüs'te defnedildiği nakledilse de ${ }^{7}$ esasen Şaban 303 'te (Şubat 916) Mekke'de vefat ettiği ve Safâ ile Merve arasında bir yere defnedildiği de iddia edilmektedir. ${ }^{8}$

Yukarıda bazıları zikredilen meşhur muhaddislere öğrencilik ve hocalık yapan Nesâînin ilmi kariyerinin parlaklığı dikkat çekmektedir. Hem yaşadığı zaman diliminde hem de sonrasında birçok âlimin/muhaddisin övgüsüne mazhar olan Nesâî'nin hadisle ilgili birçok eser oraya koyduğu, ricâl ilminde de önemli bir konumda bulunduğu anlaşılmaktadır. Kaynaklarda Nesâî, imâm, hüccet, hâfız gibi muhaddislik vasıflarıyla anılmıştır. ${ }^{9}$

Nesâî'nin itikadı ve mezhebiyle ilgili olarak bugüne kadar geniş malumatı hâvi bir kaynak tespit edemedik. Gerek Ehl-i Sünnet bağlamında kaleme alınan eserlerde gerekse Şîa kaynaklarında onun itikadı ve mezhebi ile ilgili bilgiler tekrardan öteye geçememiştir. ${ }^{10}$ Söz konusu kaynaklarda, siyasî, itikâdî ve mezhebî yaşantısı ve düşüncesiyle ilgili olarak Nesâî'nin Şiîliğine delil gösterilebilecek; Hz. Muâviye'ye dil uzatmasından dolayı dövüldüğü, hilâfet konusunda Hz. Ali tarafını tuttuğu, bu yönde eserler kaleme aldığı gibi iddialar mevcuttur. ${ }^{11}$ Fakat yine aynı ve farklı kaynaklarda Nesâînin Hz. Ali'yi Hz. Ebû Bekir ve Hz. Ömer'den üstün tutmadığı, Hz. Ali'yi fazlaca övse de bunu üstünlük addedilecek kadar ileri götürmediği, hatta Kur'ân'ın mahlûk olup olmaması tartışmalarında Ehl-i Sünnet'le aynı çizgide durduğu nakledilmektedir. ${ }^{12}$ Yukarıda bazıları zikredilen sebeplerden dolayı teşeyyu ile suçlan-

7 Bkz. es-Safedî, Selâhuddîn Halîl b. Eybek, el-Vâfî bi'l-vefeyât, (I-XXIX), thk. Ahmed Arnaûd/Türkî Mustafa, (I-XXIX), Daru'l-ihyâ'i-t türâsi'l-arabî, Beyrût, 2000, VI, 257; Subkî, Tâcüddîn Abdulvehhâb b. Takiyyuddîn, Tabakâtu'ş-şâfiîyyeti'I-kübrâ, (I-X), thk. Mahmud Muhammed et-Tanâhî, 1413, III, 16.

8 İbnu'l-Cevzî, el-Muntazam, XIII, 156.

9 İbnu'l-Cevzî, el-Muntazam, XIII, 157; Zehebî, Siyeru a'lâmi’n-nübelâ, XI, 84; a.mlf., Tezkiratü'l-huffâz, (I-IV), Dâru'l-kütübi'l-ilmiyye, Beyrût, 1998, II, 195.

10 Bu kaynaklara da dayalı olarak Nesâî'nin Şiîlikle ithamı konusu ilerleyen bölümlerde ayrıntısıyla ele alınacağından şimdilik bu eserlerin ismini zikretmiyoruz.

11 Bu iddialar için bkz. İbn Asâkir, Ebu'l-Kâsım Ali b. Hasan b. Hibetullah, Târîhu Dımeşk, (ILXXX), thk. Amr b. Garâme el- Umrevî, Dâru'l-Fikr; 1995, LXXI, 173; İbnu'l-Cevzî, elMuntazam, XIII, 155; İbn Nukta, Muhammed b. Abdilğanî b. Ebî Bekr b. Şücâ, et-Takyîd li ma'rifeti ruvâti's-sünen ve'l-mesânîd, thk. Kemâl Yusuf el-Hût, Dâru'l-kütübi'l-ilmiyye, byy., 1998, 142; Zehebî, Tezkiratü'l-huffâz, II, 195.

12 İbn Asâkir, Târîhu Dımeşk, LXXI, 173, 175; Mizzî, Ebu'l-Haccâc Yusuf b. Abdurrahman, Tehzîbu'l-Kemâl fî esmâi'r-ricâl, (I-XXXV), thk. Beşşâr Avvâd Ma'rûf, Müessesetü'risâle, Beyrût, 1980, I, 337, 338; Zehebî, Tezkiratü'I-huffâz, II, 195; İbnu'l-İmâd, Şezerâtu'z-zeheb, IV, 17; Kandemir, M. Yaşar, "Nesâî", DIA, XXII, 564. 
sa da gerçekte Nesâî'nin Şâfiî mezhebine mensup olduğu vurgulanmaktadır. ${ }^{13}$ Özellikle Sünen'i ve diğer eserleri genel olarak değerlendirilip bir kenara konulduğunda Nesâînin sadece Hz. Ali hakkında kaleme aldığı Hasâisî ve Muâviye hakkında söylemiş olduğu bir söz dolayısıyla Şiîlikle itham edilmesinin insaf ölçüsünü aştığı düşüncesindeyiz.

\section{Nesâî’nin Tartışma Konusu Olan Eserleri}

Nesâî'nin üzerinde duracağımız iki önemli eseri; Hasâisu emîrilmü'minîn Alî b. Ebî Tâlib radıyallahu anh ve Fezâiu's-sahâbe'sidir. Çünkü kendisinin Şiîlikle ithamında tartışma konusu olan hususların tamamına yakını bu iki esere dayandırılmaktadır. Bunlardan ilki onun Şiîliğine delil gösterilirken ikincisi aksi delil olarak kabul görmektedir.

\section{A. Hasâisu emîri'l-mü'minîn Alî b. Ebî Tâlib radıyallâhu anh}

Hz. Ali ile ailesinin faziletlerine dair 194 (veya) 188 rivâyeti kapsayan bu eser ${ }^{14}$ Nesâî'nin Şiîliğiyle ilgili üzerinde en fazla spekülasyon yapılan bir çalışmadır. Müellifin yaşadığı dönemde de bazı çevrelerin tenkidine maruz kalan bu eserin yazılış amacı yine bizzat müellifin kendisi tarafından açıklanmıştır. Buna göre Nesâî’ye neden Hz. Ebû Bekr ve Hz. Ömer'in faziletlerine dair bir kitap yazmadığı sorulmuş, O da "Şam'a gittiğimde insanların $\mathrm{Hz}$. Ali'den fazlaca yüz çevirdiklerini gördüm. Allah'ın onları doğru yola yönlendirmesini umarak bu kitabı yazdım" şeklinde bir cevapla kaleme aldığı bu eserin yazılış sebebini açıklamıştır. ${ }^{15}$

13 Zehebî, Siyeru a'lâmi'n-nübelâ, XI, 81; Subkî, Tabakâtu'ş-şâfiîyyeti'l-kübrâ, III, 14.

14 Eserin baskıları ve eser hakkında diğer hususlar için bkz. Nesâî, Ebû Abdurrahmân Ahmed b. Şuayb b. Alî, Hasâisu emîri'l-mü'minîn Ali b. Ebî Tâlib radıyallahu anh, Ahmed Mîrîn elBelûşî, Kuveyt, 1406/1986. Bu kitap mezkûr isimle bilinmesi yanında el-Hasâis, Hasâisu Alî, Kitâbu'l-Hasâis fî fazli Alî b. Ebî Tâlib olarak da zikredilmektedir. (Kahire, 1308, 1404/1984, Necef, 1389/1969; nşr. Kemâl Yûsuf el-Hût, Beyrut, 1403/1983 [Tehzîbü Hasâisi emîri'mü'minîn Alî b. Ebî Tâlib adıyla], nşr. Muhammed Bâkır el-Mahmûdî, Beyrut, 1983; nşr. Ahmed Mîrîn el-Belûşî, Kuveyt, 1406/1986; nşr. Ebû İshak el-Huveynî el-Eserî, Beyrut, 1407/1987; Huveynî bu eseri Tehzîbü Hasâisi'l-Imâm Alî adıyla da yayımlamıştır. Beyrut, 1404/1984. Nâim Erdoğan'ın Hadislerle Hz. Ali adıyla da tercümesini yaptığı bu eseri Yusuf Özbek yayıma hazırlamıştır (İstanbul, 1992). Kitap hakkında geniş bilgi için bkz. Kandemir, M. Yaşar, "Nesâî", DIA, XXII, 564.

15 İlgili olay için bkz. İbn Asâkir, Târîhu Dımeşk, LXXI, 173; Mizzî, Tehzîbu’l-Kemâl, I, 338; Zehebî, Siyeru a'lâmi'n-nübelâ, XI, 81; Subkî, Tabakâtu'ş-şâfiîyyeti'l-kübrâ, III, 15. 
Söz konusu kitaptaki Hz. Ali'nin üstünlüğünü vurgulayan ilk rivâyet şu şekildedir: Habbetü'l-Urenî'den: “Ali (k.v.)'nin şöyle dediğini işittim: Allah Rasûlü (s.a.v.) ile ilk namaz kılan (kişi) benim."16

Nesâî'nin bu kitabında zikredilen ilk rivâyetin ilk râvisi olan Habbetü'lUrenî (ö.76/?) birçok muhaddis tarafından Şiî ya da aşırı Şiî olmakla tenkide maruz kalmış ayrıca sika olmadığı, metrûk bir râvi olduğu da nakledilmiştir. ${ }^{17}$ Fakat zayıf isnatla nakledilen bu rivâyet hemen peşinden sahîh bir senetle tekrar verilmiştir. ${ }^{18}$

Eserde geçen rivâyetleri tek tek ele alıp tahrîc etmek bu araştırmanın amacı dışında ve hacmi üzerinde bir uygulama olacağı düşüncesinden hareketle konuyla direkt bağlantısı olan bazı rivâyetler ele alınmıştır. Çünkü Nesâînin Şiîliğine dair tartışma çıkarmış olma intimali göz önünde bulundurularak bazı rivâyetler ve bunların mahiyeti hakkında bilgi vermenin, müellifin Şiîlikle ithamı hakkında bir kanaat oluşturmada daha isabetli olacağı düşüncesindeyiz.

Eserde genel olarak senetleri farklı fakat muhteva yönünden aynı rivâyetler birbiri ardınca veya farklı yerlerde ele alınmıştır. Daha önce de zikredildiği gibi bu rivâyetlerin hemen hepsi Hz. Ali ve Ehl-i Beyt'in fazileti, üstünlüğü ve sevgisi ile ilgilidir. Umumiyetle Hz. Ali ve Ehl-i Beyt lehine olan rivâyetler işlenmiş olsa da bazı yerlerde Şiî taraftarlara da üstü kapalı bir mesaj niteliği taşıyan rivâyetlerin yer aldığı görülmektedir. Bu rivâyetlerden biri şu şekildedir: "Bir kişi İbn Ömer'e, Osman hakkında sordu. O da şu cevabı verdi: O (Osman), iki ordu karşılaştığı gün, harbe iştirak etmeyenlerdendi. Sonra Allah onu affetti. Günah işledi (hata etti), bu günahı (hatası) öldürülmesine neden oldu. Sonra (aynı kişi İbn Ömer'e) Ali hakkında sordu. Şu cevabı aldı: Onun hakkında sorma! Ali'nin, Allah Rasûlü'nün nezdindeki mertebesini görmüyor musun?"19

Rivâyetin benzeri, başka bir yerde ama farlı bir senetle şu şekilde: nakledilmektedir “....Mescidin içinde sadece Ali'nin odası vardır. Osman'a

\footnotetext{
16 Nesâî, Hasâis, s. 21.

17 Mizzî, Tehzîbu'l-Kemâl, V, 352-355; İbn Hacer el-Askalâni, Ebu'l-Fadl Ahmed b. Ali b. Muhammed b. Ahmed, Mîzânü'l-l'tidâl fî nakdi'r-ricâl, (I-IV), Ali Muhammed el-Becâvî, Dâru'lma'rife, Beyrût, 1963, I, 450.

18 Bkz. Nesâî, Hasâis, s. 21.

19 Nesâî, Hasâis, s. 122.
} 
gelince, küçük bir hata yaptı, tutup onu öldürdünüz..."20 Birinci rivâyette $\mathrm{Hz}$. Osman'ın hatalı da olsa Allah'ın affına mazhar oluşu ikincisinde de öldürme filiyle kendisine haksızlık yapılması tesadüfen nakledilmekten ziyade Nesâî tarafından kullanılmış sübliminal bir mesaj şeklinde de anlaşılabilir.

Fakat Muâviye aleyhine fazla olmasa da birbirinin devamı niteliğinde rivâyetler geçmekle birlikte bunlardan çok azında bizzat Muâviye'nin ismi zikredilmektedir. ${ }^{21}$ Bunlar farklı senetlerle gelen aynı rivâyetlerdir. Bu durumda Muâviye aleyhine olup konuları ayrı ayrı senetler sayılmadığı takdirde farklı olarak üç olayın nakledildiği görülmektedir. Farklı senetle gelen aynı rivâyetten biri şu şekildedir: "Muâviye, Sa'd b. Ebî Vakkâs'a emretti (şöyle söyledi): Ebû Turâb'a (Ali'ye) sövmekten seni alıkoyan nedir? Sa'd: Allah Rasûlü'nün ona söylediği üç şey vardır ki, onları hatırlayınca ben ona asla sövmem!..."22 Muâviye ile ilgili farklı olan diğer rivâyet ise uzun bir şekilde Sıffîn savaşının anlatıldığı olaydır. ${ }^{23}$ Bu iki rivâyet dışında Muâviye'nin bizzat isminin zikredildiği diğer nakil ise Ammâr b. Yâsir'in öldürülmesiyle ilgili kendisinin “...Onu biz mi öldürdük" sözlerinin yer aldığı rivâyettir. ${ }^{24}$

Kanaatimizce Nesâî'nin Hz. Ali ve Ehl-i Beyt'e yönelik özel sevgisini diğer halifeler ve aileleriyle ilgili mukayese tarzındaki rivâyetler çerçevesinde de ele alması eleştiri oklarını üzerine çekmiştir. Müellifin naklettiği bu tür rivâyetlerin bir kısmında Hz. Ali'nin diğer halifelerle mukayese edilip üstün yönlerinin vurgulandığı görülmektedir. Enes b. Mâlik'ten nakledilen bu rivâyetlerden biri şu şekildedir: Peygamber (s.a.v.)'in yanında pişmiş kuş eti vardı ve şöyle dua etti: "Allah'ım! Yarattıkların içinde en çok sevdiğim kimseyi getir de benimle bu kuşun etinden yesin." Ebû Bekr geldi, onu geri çevirdi, Ömer geldi, onu da geri çevirdi. Sonra Ali geldi, onun yemesine izin verdi... ${ }^{25}$ Kütüb-i Sitte'de sadece Tirmizî'de geçen bu rivâyet ${ }^{26}$ "zayıf" kabul edilmiştir. Senette yer alan Müshir b. Abdülmelik ta'dîl edilmekle birlikte zayıf, leyyin olarak da cerhe

\footnotetext{
20 Nesâî, Hasâis, s. 123.

21 Muâviye'nin isminin zikredildiği bu rivayetlerin geçtiği yerler için bkz. Nesâî, Hasâis, s. 37, 73, 164, 174, 192.

22 Nesâî, Hasâis, s. 30. Farklı senetle gelen diğer rivâyet için bkz. Nesâî, Hasâis, s. 73.

23 Bkz. Nesâî, Hasâis, s. 191, 192.

24 Nesâî, Hasâis, s. 174. Ammâr b. Yâsir hakkındaki söz konusu olayla ilgili geniş bilgi için bkz. Ural, Cemal, Ammâr b. Yâsirin Azgın Bir Topluluk Tarafından Öldürüleceğine Dair Rivayetin Hadis Tekniği Açısından Tahlili, Basılmamış Yüksek Lisans Tezi, Elazığ 2017.

25 Nesâî, Hasâis, s. 29.

26 Bkz. Tirmizî, Menâkıb, 20.
} 
maruz kalmış ayrıca hadislerinin yazılabileceği fakat delil olamayacağı söylenmiştir. ${ }^{27}$

Hz. Ali'nin efdaliyeti ile ilgili diğer rivâyet ise şu şekildedir: Abdullah b. Bureyde babasından naklen şöyle dedi: "Hayber'i kuşattık, Ebû Bekr sancağı aldı, fethedemedi. Ertesi gün Ömer sancağı aldı, o da fethedemeden döndü. İnsanlar yorgun düşmüşlerdi. Bunun üzerine... Allah Rasûlü gözleri ağrımakta olan Ali b. Ebî Tâlib’i çağırdı... ve sancağı ona teslim etti. Bunun üzerine Allah fethi onun elinde müyesser kıldı..."28 Bu rivâyet muhteva bakımından hemen hemen aynı şekilde farklı senetlerle peş peşe sekiz defa zikredilmiştir. Sahîh senetlerle birlikte zayıf senetlerle de nakledilen bu rivâyetin muteber hadis eserleri ${ }^{29}$ yanında fedâil, hasâis, delâil, menâkıb türü eserlerin vazgeçilmezleri arasında olduğu görülmektedir ${ }^{30}$ Buna ilaveten Nesâînin bu eserinde yine mukayese tarzında $\mathrm{Hz}$. Ali'nin efdaliyetiyle ilgili olarak dört farklı olayın anlatıldığı rivâyet, ${ }^{31}$ ayrıca Hz. Fatıma, Hz. Hasan ve Hz. Hüseyin'in faziletleriyle ilgili de değişik rivâyetler yer almaktadır. ${ }^{32}$

Tabii olarak hasâis ve fedâil türü eserlerin mahiyeti, ele alınan şahsı övme, edebi bir üslûpla onun farklı özelliklerini ön plana çıkarmayı hedeflediğinden Hz. Ali'nin mukayese şeklinde faziletlerinin işlenmesi yadırganacak bir durum olmamalıdır. Nihayetinde diğer bazı sahabe için de buna benzer tarzda eserler kaleme alınmıştır. Burada önemli olan husus bir şahsın fazilet ve üstünlüklerini diğer şahsın/şahısların hicvinde temellendirmemektir. Nesâî'nin Hasâis adlı eseri baştan sonra tetkik edildiğinde, zikredilen bu üslûp ve metodun geçerli olduğu açıkça görülecektir. Zaten yukarıda da bahsedildiği gibi Sünnî bazı âlimler bu hususta müstakil bazı eserler kaleme almış ve genel İslam tarihi kitaplarında bu olaya geniş yer ayırmışlardır. Çünkü Hz. Peygamber'in torunu olan $\mathrm{Hz}$. Hüseyin'in de öldürülmesi bütün İslam aleminde yer

27 Râvi hakkında daha geniş bilgi için bkz. Mizzî, Tehzîbu'l-Kemâl, XXIIV, 577, 578; Zehebî, Ebû Abdullâh Şemseddîn Muhammed b. Ahmed b. Osmân, Mîzânu'l-i'tidâl fî nakdi'r-ricâl, (I-IV), thk. Ali Muhammed el-Becavî, Dâru'l-marife, Beyrût, 1963, IV, 113. Ayrıca bkz. Nesâî, Hasâis, s. 29. (Muhakkikin dipnotu).

28 Nesâî, Hasâis, s. 40, 41.

29 Mesela bkz. Buhârî, Ashabü'n-nebî, 9; Ahmed b. Hanbel, XXXVIII, 98.

30 Rivâyetin geçtiği diğer yerler ve değerlendirmeler için bkz. Nesâî, Hasâis, s. 39-44.

31 Bu rivâyetler için bkz. Nesâî, Hasâis, s. 54, 92, 93, 136, 166.

32 Bkz. Nesâî, Hasâis, s. 141-144, 146, 149-151. 
alan edebiyatta derin izler bırakmış ${ }^{33}$ bu etki Hz. Ali'nin şahsında Ehl-i Beyt sevgisiyle birlikte müstakil bir edebiyat halini almıştır.

\section{B. Fedâilu's-sahâbe}

Amellerin, vakitlerin, şahısların, şehir, ülke ve milletlerin faziletini anlatan bir kitap türü olan "Fedâil'ler"de Hz. Peygamber'in ve ashabın faziletleriyle ilgili olanlar önemli yer tutar. ${ }^{34}$ Nesâî'nin Fezâiu's-sahâbe'si bu türde yazılmış ilk eserlerdendir. Bu eser, müellifin es-Sünenü'l-kübrâ'sında yer alan altmış kadar sahabe, ensar ile Hz. Meryem ve Âsiye'nin faziletlerini içeren 284 rivâyetten meydana gelmektedir. ${ }^{35}$

Daha önce de zikredildiği gibi Nesâî, Şam'daki bazı kimselerin Hz. Ali aleyhine olan tavırlarından dolayı Hasâis adlı eserini kaleme alarak $\mathrm{Hz}$. Ali ve Ehl-i Beyt'in faziletine dair rivayetleri cem ettiğini, açıkça söylemiştir. Kendisine Muâviye'nin faziletine dair rivayetleri neden cem etmediği gibi sorulara da karşı çıkmıştır. Neticede Hz. Ali'den başka diğer sahabe hakkında faziletleri nakleden bir eser yazması için yapılan taleplerden dolayı Hasâis"den sonra Fedâilü's-Sahâbe adlı kitabını telif etmiştir. Tabii ki diğer Fedâil türü eserlerinin ortaya çıkış sebebi olan ashabın bir kısmına karşı olan kötü tutumlar, Nesâî'nin bu kitabını telif etmesine sebep olan diğer bir unsur olarak değerlendirilebilir. ${ }^{36}$

Hz. Ebû Bekr'in faziletiyle ilgili rivâyetlerle başlayan eserde daha sonra hilafete geçiş sırasına göre $\mathrm{Hz}$. Ömer, Hz. Osman ve Hz. Ali'nin faziletlerine dair rivayetler nakledilmiştir. Hz. Ebû Bekir'in faziletini konu alan dokuz rivayet peş peşe verildikten sonra Hz. Ebû Bekir ve Hz. Ömer'in faziletlerinin birlikte ele alındığı rivâyetler daha sonra ise bu iki halifeye $\mathrm{Hz}$. Osman'ın da eklenerek üçünün faziletlerini konu alan rivayetler sıralanmıştır. ${ }^{37}$ Bundan sonra sadece $\mathrm{Hz}$. Ali'nin faziletine dair rivayetler verilmiş, ${ }^{38}$ hemen arkasından

33 Yıldırım, "El-Hâkim en-Neysâbûrî̀nin Şiîlikle İtham Edilmesi”, s. 75.

34 Kandemir, M. Yaşar, "Fezâil", DIA, XII, 529.

35 Bu eser hakkında geniş bilgi için bkz. Aslan, Hasan, Hadis Literatüründe Fedâilü'sahâbe Türü Kaynaklar ve Nesâînin "Fedâilü's-sahâbe'si", Şırnak Üniversitesi Sosyal Bilimler Enstitüsü, Basılmamış Yüksek Lisans Tezi, Şırnak, 2017.

36 Nesâînin bu eseri yazma amacı hakkında bkz. İbn Asâkir, Târîhu Dımeşk, LXXI, 174; Mizzî, Tehzîbu'l-Kemâl, I, 338.

37 Nesâî, Fedâilü's-Sahâbe, s. 3-31.

38 Nesâî, Fedâilü's-Sahâbe, s. 13. 
yine dört halifenin tamamına dair rivayetler sıralanmıştır. ${ }^{39} \mathrm{Bu}$ kısımdan sonra Câfer b. Ebû Tâlib, Hz. Hasan, Hz. Hüseyin, Hamza, Abbas, Abdullah b. Abbas, Zeyd ve Usâme gibi Ehli Beyt'ten olan veya onlara yakın isimlerin faziletlerini bildiren rivayetlere yer verilmiştir. ${ }^{40}$ Bütün bu isimlerin $\mathrm{Hz}$. Ali'ye yakın olması dikkat çekmektedir. Buna karşın Muâviye'nin fazileti hakkında hiç rivayette bulunulmaması, Amr b. el-Âs hakkında da sadece bir rivayette bulunulması ${ }^{41}$ dikkat çeken hususlardandır. Ayrıca Dört halifenin fazileti başlığı altında "Ümmetimde halifelik otuz yıldır, sonrası hanedanlıktır. Hesapladık ve gördük ki, bunlar Ebû Bekr, Ömer, Osman ve Ali'dir"42 rivayetine yer verilmesi, Nesâî'nin sadece Muâviye ve Emevî hanedanına değil sonraki yönetimlere bakış açısını yansıtması şeklinde de yorumlanmıştır. ${ }^{43}$ Nesâî, "Hz. Peygamber'in ashâbı hakkında menkıbeler ve onlara kötü söz söylenmesinin yasaklanması" başlığı altında ashâbın kınanmaması, onlara dil uzatılmaması ile ilgili iki rivayete yer vermektedir. Kanaatimizce müellif bu rivâyeti bir denge unsuru olarak görüp eserine kasıtlı almıştır. Hatta bu iki rivâyetten önce, ele alacağı konunun önemine vurgu mahiyetinde önce bazı ayetler zikretmiş sonra birbirinin tekrarı olan "Ashâbımı kınamayın, sizden birisinin Uhut Dağı kadar altını olsa ve infak etse onların bir avuçluk sevabına veya yarısına ulaşamaz" rivâyetini nakletmiştir. ${ }^{44}$

Başta dört halife ve diğer sahabe ile ilgili rivâyetler eserin temelini oluşturmakla birlikte Ensâr ve Muhâcir'in fazîletlerinin anlatıldığı birçok rivayetin kitapta yer aldığı görülmektedir. ${ }^{45} \mathrm{~Hz}$. Ebû Bekir'in ve Hz. Ömer'in Muhâcir'den olmaları ve hicretlerinden dolayı övülmeleri, Hz. Peygamber'in Ensâr ve Muhâcir'e dua etmesi, Ensâr devrinin övülmesi, Ensârı sevmeye teşvik gibi hususlar bu rivâyetlerden bazılarıdır. ${ }^{46}$ Bunlar dışında bazı kabilelerin ve yine kadın sahabeden bazılarının, ayrıca sahabeden olmayan Hz. Mer-

39 Nesâî, Fedâilü's-Sahâbe, s. 17.

40 Nesâî, Fedâilü's-Sahâbe, s. 17-25.

41 Nesâî, Fedâilü's-Sahâbe, s. 59.

42 Nesâî, Fedâilü's-Sahâbe, s. 17.

43 Büyükkara, Hadis Literatüründe Fedâilü'sahâbe Türü Kaynaklar ve Nesâî'nin "Fedâilü'ssahâbe'si", s. 84.

44 Nesâî, Fedâilü's-Sahâbe, s. 61, 62. Bu rivâyet için bkz. Buhârî, Ashâbu'n-Nebiyy, 6; Müslim, Fedâilü's-sahâbe, 54; Ahmed b. Hanbel, XVII, 138; İbn Mâce, Îmân, 11.

45 Nesâî, Fedâilü's-Sahâbe, s. 62-72.

46 Bu ve diğer rivâyetler için bkz. Nesâî, Fedâilü's-Sahâbe, s. 62-72. 
yem, Asiye, Hacer ve Sara'nın faziletlerinin anlatıldığı rivayetlere de yer verilmiştir. ${ }^{47}$

\section{Siyasi Olaylar ve Mezhepsel Faaliyetler Karşısında Nesâî}

Nesâî'nin yaşadığı zaman diliminde Dımeşk'te ${ }^{48}$ ağırlıklı olarak Abbâsî hakimiyeti görülmesine karşın kısa süreli de olsa Türklerin, Tolunoğulları ve Karmatîler gibi grup veya beylik tarzı güçlerin bölgede etkisi olduğu kaynaklarda yer almaktadır. ${ }^{49}$

Abbâsîler, hâkimiyetlerinden kısa süre sonra hilâfet merkezi olarak Suriye yerine Irak'ı tercih ettiler. Tabii ki hilâfet merkezinin değişmesinin önemli sosyal ve siyasal sonuçları olmuştur. Bu değişiklikle idarenin ağırlık merkezi, bir Akdeniz ülkesi olan Suriye'den, sulanabilen zengin bir vadi ve birçok ticaret yollarının kavşağı olan Irak'a geçmiş, böylece Bizans yerine İran'ın tesiri yoğunluk kazanmıştır. ${ }^{50} \mathrm{Her}$ ne kadar yönetimde Abbâsîler hâkim ise de İran nüfuzunun devletin değişik kademelerinde hâkimiyetinin olduğu bazı uygulamalardan açıkça anlaşılıyordu. Abbâsîlerin ilk zamanlarında iktidarın Emevîler'den devralınmasından itibaren devlet yönetiminde ağır bir mevâli baskısının olduğu hatta Ebû Müslim'in büyük bir nüfuz ve iktidar sahibi olduğu, ilk Abbâsî halifesinin âdeta onun gölgesinde yaşadığı kaynaklarda zikredilmektedir. Fakat daha sonra bu durumdan rahatsız olan Halife Mansûr, Ebû Müslim'in bu hâkimiyetine tahammül edemeyerek onu öldürttü. Ancak bununla devlet içindeki İran nüfuzu kırılmış olmuyordu. Bermekî vezir ailesi, Mansûr devrinden itibaren uzun müddet iktidarını devam ettirdi. Bu sefer de Bermekîler devlet içinde halife kadar kudret sahibi olmuşlardı. ${ }^{51}$ Neticede İran etkisinin Abbâsî devletinin idaresinde uzun süre etkisini göstermeye devam ettiği anlaşılmaktadır. Yine Abbâsîlerin Şam'a hâkim olmalarına rağmen zaman zaman bölgenin demografik yapısı itibariyle de değişik zamanlarda ayaklanmaların olduğu görülmektedir.

47 Nesâî, Fedâilü's-Sahâbe, s. 73-87.

48 Nesâî her ne kadar Horasan'da doğmuş olsa da bu bölümde onun ilmi faaliyetlerini devam ettirmek üzere geldiği Şam ele alınacak ve bu bölgeye dikkat çekilecektir. Çünkü Nesâînin Şiîlikle suçlanmasının temel sebeplerinden olan tartışmalar bu bölgede yaşanmıştır.

49 Geniş bilgi için bkz. Zehebî, İber, I, 265-444; Tomar, Cengiz, "Şam", DiA, XXVIII, 312.

50 Yıldız, Hakkı Dursun, "Abbâsîler", DiA, I, 34.

51 Mahmut Şakir, Hz. Adem'den Bugüne İslam Tarihi, (çev. Ferit Aydın), Kahraman Yayınları, İstanbul, 2004, IV, 140, 141; Yıldız, "Abbâsîler", DIA, I, 34. 
Abbâsîler dönemi, diğer İslâmî ilimler gibi Kelâm ilminin de sistemleştiği, bazı itikadî mezheplerin kurulup geliştiği, bazılarının da sönüp gittiği bir dönemdir. Emevîler devrinde ortaya çıkan Mu'tezile mezhebi Halife Me'mûn, Mu'tasım ve Vâsik dönemlerinde en parlak devrini yaşamış ve Abbâsî coğrafyasında taraftarlarını çoğaltmıştır. Bağdat'taki Mu'tezile mensupları, halifeler nezdinde itibar kazanmaya çalışarak kendi görüşlerini devletin resmî mezhebi haline getirmişlerdir. Bilhassa "Halku'l-Kur'ân" meselesinde Sümâme b. Eşres ve İbn Ebû Düâd, Halife Me'mûn ve ayrıca Mu'tasım'ın huzurunda Ahmed b. Hanbel ile yaptıkları münazaralar sonunda "mihne" devrinin ${ }^{52}$ ortaya çıkmasına yol açmışlardır. Abbâsî idaresinin ikinci asrında Sünnî akîdeyi savunan İbn Küllâb el-Basrî, Hâris el-Muhâsibî, Buhârî, Ebû Ali el-Kerâbisî, Dârimî gibi âlimlerin Ehl-i Sünnet kelâm ilminin doğmasına zemin hazırlamasından sonra, Ebü'l-Hasan el-Eş'arî tarafından kurulan Ehl-i Sünnet kelâmı giderek gelişmiş ve Bâkıllânî, İbn Fûrek, Abdülkâhir el-Bağdâdî, Cüveynî, Gazzâlî, Râzî gibi âlimlerin eserleriyle kökleşmiştir. Eş'arî ekolüne paralel olarak Mâverâünnehir'de Ebû Mansûr el-Mâtürîdî tarafından kurulan ikinci Sünnî kelâm mektebinin ortaya çıkışı ${ }^{53}$ ve yayılışı da Abbâsîler zamanına rastlar. Şîa, Havâric ve Mürcie mezheplerinin birçok fırkaya ayrılması da Abbâsîler zamanında vuku bulmuştur. Bu devirde söz konusu mezhep mensuplarının zaman zaman halifelerin aleyhinde bulunmaları, bazen iç savaşlara ve siyasî karışıklıklara da yol açmıştır. ${ }^{54}$

İktidarın elden ele geçtiği, mezhepsel faaliyet ve mücadelelerin yoğunluğunu devam ettirdiği bu dönemde Nesâî'nin söz konusu faaliyet, mücadele ve tartışmalardan uzak durduğu görülmektedir. Çünkü ileride de ele alınacağı gibi Nesâî'nin hayatının anlatıldığı kaynaklara bakıldığında kendisinin açık bir şekilde iktidar, mezhep vs. tartışma ve mücadelesinin olmadığı görü-

52 Bazı Abbâsî halifeleri döneminde halku'l-Kur'ân konusunda bazı âlimlerin sorguya çekilip eziyet edilmesine ilişkin olaylara verilen ad. Mu'tezilî olmayan fakihlerin ve ehl-i hadîsin inanç ve düşünceleri üzerinde baskı ve şiddet uygulamaktan kaynaklanan mihne siyasetinin ortaya çıkışında Mu'tezile kelâmcılarının Abbâsî halifesini etkilemesinin rol oynadığı genellikle kabul edilir. Ancak Merv'in hilâfet merkezi olarak seçilmesi ve Fazl b. Sehl'in vezir yapılmasında olduğu gibi İran asıllı kişilerin yönetimde etkin oluşunun yanı sıra Me'mûn'un bazı uygulamalarının başta Bağdat olmak üzere çeşitli vilâyetlerde ayaklanmalara sebep olduğu, Ali evlâdının da bazı vilâyetlerde iktidarı ele geçirmek için isyan etmesi gibi hususlar göz önünde bulundurulduğunda mihne siyasetinin kaynağını yalnızca bir inanç kaygısına indirgemenin mümkün olmadığı görülür. Yücesoy, Hayrettin, "Mihne”, DIA, XXX, 27.

53 Mâtürîdî'nin Sünnî kelamındaki yeri ve önemi için bkz. Önal, Recep, "Mâtürîdî’nin Hayatı, Eserleri ve Kelam İlmi'ndeki Yeri”, Akademik Incelemeler Dergisi, 8, 3 (2013), ss. 325-360.

54 Yıldız, "Abbâsîler", DiA, I, 42, 43. 
lecektir. Söz konusu kaynaklarda Nesâî'nin Şiîlikle suçlanması yanında kendisinin Şâfiî mezhebine mensup olduğu ${ }^{55}$, yaşadığı dönemde hala aktüelliğini koruyan Kur'ân'ın mahluk olup olmadığı konularında yapılan tartışmalarda da pek yer almadığı görülmektedir. ${ }^{56}$

\section{Nesâî'yi Anlatan Kaynaklar}

Nesâî'nin Şiîlikle ithamında takip edilmesi gereken yollardan biri de hem Ehl-i Sünnet hem de Şîa kaynaklarını taramaktır. Ricâl edebiyatında Nesâî hakkında ileri sürülen iddialar ve bunların sıhhati göz önünde bulundurulmadan her hangi bir yargıda bulunmak isabetli yöntem olmasa gerektir. Bunun için Ehl-i Sünnet ve Şîa çizgisinde telif edilmiş kaynaklarda Nesâî'nin biyografisi ayrı ayrı ele alınacak, Şiîlikle ithamında ileri sürülen deliller irdelenecektir.

Usûl ve litaratür de dâhil edilerek hadis tarihine genel olarak bakıldığında Ehl-i Sünnet muhaddislerinin, hadisleri ulaştıran ravilerin ve rivayetleri cüzlerde veya kitaplarda derleyenlerin kendilerine yakın çizgide olmalarına genellikle ehemmiyet verdikleri görülecektir. Çünkü farklı kabulleri benimsemiş ve bid'at şeklinde tanımlanmış gruplara bağlı veya bunlara meyyal olanlar her zaman risk olarak kabul edilmiştir. En azından, kendi meşreplerine uygun rivayetlere ve ravilere toleranslı davranmış olmaları her zaman ihtimal dâhilindedir. Bu nedenle muhaddisler kişinin farklı çizgide olduğunu gösteren bir işaret veya değerlendirme gördüklerinde buna dikkat kesilirler. Onun propagandist olup olmadığına bakılır, bir şekilde rivayetlerine kapı aralansa da yine de kendisine karşı intiyatlı bir yaklaşım sergilenir. ${ }^{57}$ Ehl-i Sünnet'in yukarıda zikredilen kendi çizgilerine yakın olanları benimseme yapısı elbette ki Şîa için de geçerlidir. Buna ilaveten hadis ricâli de dâhil olmak üzere Şîa'nın kendi mezhep kapsamındaki muhaddislerin/âlimlerin rivâyet ve değerlendirmeleri çevresinde oluşturdukları dokunulmazlık/koruyuculuk zırhının neredeyse delinemeyecek derecede muhkemleştirildiğini söylemek mübalağa olmasa gerektir. Nesâî de dâhil olmak üzere bütün ekollere mensup muhaddisler/âlimler ve

\footnotetext{
55 İbn Asâkir, Târîhu Dımeşk, LXXI, 176.

56 Kaynaklarda Nesâî'nin hala devam eden Kur'ân'ın mahluk olup olmadığıyla ilgili tartışmalara yönelik olarak Abdullah b. Mübarek ile aynı görüşte olduğu bilgisi yer almaktadır. Bu konuda geniş bilgi için bkz. İbn Asâkir, Târîhu Dımeşk, LXXI, 172; Zehebî, Tezkiratü'l-huffâz, II, 195.

57 Geniş bilgi için bkz. Yıldırım, "el-Hâkim en-Neysâbûrî̀nin Şiîlikle İtham Edilmesi”, s. 58.
} 
diğer şahıslar hakkındaki değerlendirme ve yargılar, zikredilen kabuller göz önüne alınarak yapılmadıkça nesnel bir sonucun oraya çıkması beklenemez.

Hadis edebiyatı kapsamında şahıs (râvi/ricâl) bulmakta faydalanılan birçok eserde Nesâî'nin biyografisine rastlamak mümkündür. Bu tür eserlerde genelde takip edilen belli bir yöntemle ele alınan şahısların doğum, ölüm, hoca, talebe, rıhle, ilim, mezhep, itikat ve siyasi düşünce olmak üzere daha birçok bilgilerine yer verilir. Ehl-i Sünnet ekolünü temsil eden râvî/ricâl edebiyatında olduğu gibi Şîa'nın temel aldığı râvî/ricâl edebiyatı da aynı metodu haizdir denilebilir. Fakat dikkat edilmesi gereken husus Şîa kaynaklarının daha geç dönemde teşekkül etmesi ayrıca râvi tenkîdinde Ehl-i Sünnet anlayışının kabul edemeyeceği bazı kriterlerinin olmasıdır. Biz de bu kısımda aynı ve farklı ilke ve esasları göz önünde bulundurarak Nesâînin biyografisini ele alacağız. Müellifi anlatan bütün kaynaklarda geçen bilgileri olduğu gibi buraya nakletmekten ziyade Şiîlik ithamıyla ilgili lehine ve aleyhine olanları seçmenin konu sınırına ve ana temaya uygun olacağı kanaatindeyiz.

Nesâî'nin Şiî olduğuyla ilgili en önemli argüman Muâviye hakkındaki değerlendirmeleridir. Özellikle Ehl-i Sünnet ekolünü temsil eden ricâl edebiyatına bakıldığında ömrünün sonlarına doğru Mısır'dan ayrılıp Dımeşk'e yerleştiği nakledilen Nesâî'nin, Muâviye hakkında yöneltilen sorulara Muâviye taraftarlarını memnun etmeyecek türden cevaplar verdiği, yine Muâviye'yi öven sözler söylenmesi istendiğinde bunu yerine getirmedi kaynaklarda yer almaktadır. Müellifin söz konusu aykırı cevabı ve isteksizliği neticesinde teşeyyu ile suçlandığı ve mescitten çıkarılarak dövüldüğü kaynaklarda yer almaktadır ki devamında da bu darbeler neticesinde vefat ettiği belirtilmektedir. ${ }^{58}$ Ehl-i Sünnet çizgisindeki kaynaklarda Muâviye hakkında Nesâî’ye nispet edilen olumsuz açıklama ve tavırların sadece bundan ibaret olmadığı görülmektedir. Kendisine Hz. Ali hakkında yazdığı fedâil türü bir eserin benzerini neden Muâviye hakkında da yazmadığı sorulduğunda "Onun hakkında neyi yazacakmışım, Ey Allah'ım! Muâviye'nin karnını doyurma" şeklinde bir cevap verdiği de nakledilmiştir. ${ }^{59}$ Fakat bazı ilim adamlarınca Nesâînin bu cevabı eleştiri gibi görülse de aslında bu bir eleştiri değil aksine Muâviye'nin faziletini ortaya koyan bir söz olarak da değerlendirilmiştir. Çünkü Hz. Peygamber'den “Ey Allah'ım ben ancak bir beşerim, diğer beşerin sinirlendiği gibi ben de sinirlenirim. Ben kime

58 İbnu'l-Cevzî, el-Muntazam, XIII, 156.

59 İbn Asâkir, Târîhu Dımeşk, LXXI, 173-174; Zehebî, Siyeru a’lâm, XI, 81. 
lanet ettiysem veya kime sebbettiysem bunu, o kimse için bir zekat ve rahmet olarak kı" şeklinde nakledilen bu rivayeti60 söz konusu âlimler Muâviye için bir dua dolayısıyla bir fazilet olarak yorumlamışlardır. Çünkü bu rivâyete göre $\mathrm{Hz}$. Peygamber kime lanet edip kötü söz söylemişse bunlar sözün söylendiği kişi için bir temizlenme ve rahmet olarak değerlendirilmiştir. ${ }^{61}$ Muâviye'nin fazileti hakkında neden bir eser kaleme almadığının sorulması üzerine Nesâî'nin gerek yukarıdaki cevabı gerekse kaynaklarda yer alan buna benzer diğer cevabı $^{62}$ temelde Muâviye aleyhine bir cevap olarak anlaşılsa da bunun yanlış olduğu müellifin dilinden başka bir nakille aktarılmaya çalışılmıştır. Buna göre Rasûlullâh'ın sahabîsi Muâviye hakkında Nesâî̀ye ne düşündüğü sorulması üzerine Nesâî şu şekilde cevap vermiştir: "İslâm, kapısı olan bir ev gibidir. İslâm'ın kapısı sahabedir. Aslında (bir eve girmek için) kapıyı döven gibi her kim sahabeye eziyet etmek isterse (bilsin ki) bununla İslâm'a eziyet etmek istemiştir. İşte kim de Muâviye (yi eleştirirse) bununla sahabeyi eleştirmek istemiştir."63

Nesâî'nin teşeyyu ile suçlanmasına sebep olan diğer bir olay Hz. Ali hakkında yazdığı Fedâil türü eserin benzerini neden Hz. Ebû Bekir, Hz. Ömer ve Hz. Osman hakkında da yazmadığıdır. Başlangıçta bu olay müellifin Şiîlikle suçlanmasına sebep teşkil etmiş olsa da Nesâînin, olayın sebebine dair verdiği cevabı ve daha sonra diğer üç halifenin de faziletlerini içeren Fedâilu'ssahâbe adlı bir eser kaleme alması teşeyyu suçlamasının sağlam temellere dayanmadığını göstermektedir. Yukarıda da bahsedildiği gibi Nesâî diğer halifelerden önce $\mathrm{Hz}$. Ali'nin faziletine dair kaleme aldığı bu kitabı yazma nedeni olarak; bulunduğu çevrede Hz. Ali'ye aleyhine oluşmuş aşırı reaksiyona karşı bir tepki şeklinde göstermektedir. ${ }^{64}$

Ehl-i Sünnet ekolünü temsil eden râvî/ricâl edebiyatında Nesâîye yöneltilen Şiîlik suçlamasının nedenleri temelde yukarıda bahsedilenlerden ibaret olmakla birlikte bu tartışmada Şîa ricâl edebiyatına müracaat etmenin de bir zorunluluk olduğu kanaatindeyiz.

\footnotetext{
60 Bkz. İbn Asâkir, Târîhu Dımeşk, LXXI, 174.

61 İbn Asâkir, Târîhu Dımeşk, LXXI, 173-174.

62 Bkz. İbn Asâkir, Târîhu Dımeşk, LXXI, 175; Mizzî, Tehzîbu'l-Kemâl, I, 339.

63 İbn Asâkir, Târîhu Dımeşk, LXXI, 175, 176; Mizzî, Tehzîbu’l-Kemâl, I, 339.

64 İbn Asâkir, Târîhu Dımeşk, LXXI, 174.
}

ÇÜiFD, 2018, cilt: 18, sayı: 1, ss. 167-191 
Daha önce de zikredildiği gibi Şîa ricâl edebiyatının teşekkülü Ehl-i Sünnet ekolüne göre geç olmuştur. Çünkü Usûl-i Erbaa'nın telif edildiği zamanda İmâmiyye'nin müstakil olarak cerh ve ta'dîle yönelik kitaplarının olmadığı, Usûl-i Erbaa'nın diğer adıyla Usûl-i Kütüb-i Ricâfin aynı zamanda cerh ve ta'dîl kitabı olduğudur. Bunun en önemli sebebi, İmâmiyye Şîa'sında Ehl-i Sünnet'te olduğu kadar cerh ve ta'dîl ilminin gelişmemiş olmasıdır. ${ }^{65}$

Nesâi'nin biyografisiyle ilgili verilen bilgilere bakıldığında ise Ehl-i Sünnet çizgisindeki klasik ricâl edebiyatında olduğu gibi Şîa ricâl edebiyatında da müellif hakkında isim, doğum, ölüm, eserler vs. genel bilgilere yer verildiği görülmektedir. Fakat Şîa'ya ait ricâl edebiyatında Nesâînin Şiîliğine dair kayda değer her hangi bir bilgi bulunmamaktadır. ${ }^{66}$ Müellif hakkında verilen bilgilerde genelde et-Tûsînin (ö. 460/1067) Fihrist'ine atıf yapılmakta ve bu eserde Nesâî hakkında fazla bir bilgi bulunmadığı da belirtilmektedir. ${ }^{67}$ Şîa ricâl edebiyatının ilk dönem kaynaklarında Nesâî hakkında geniş bir bilgiye ve özellikle de onun Şiîliğiyle ilgili her hangi bir malumata rastlanmamaktadır. Fakat son dönem eserlerinde Ehl-i Sünnet ricâl edebiyatı referans alınarak müellifin Şiîlik ithamını da kapsayan geniş bilgiler yer aldığı görülmektedir. Şiî müelliflerden Tüsterî'nin (ö. 1995) Kâmûsü'r-ricâl adlı eserinde Nesâî'nin Şîilikle suçlanmasına sebep teşkil eden ve daha önce Ehl-i Sünnet kaynakları esas alınarak zikredilmiş olan bazı olaylar nakledilmektedir. Mesela Muâviye'nin fazileti konusunda Nesâî'ye neden bir kitap telif etmediğinin sorulması üzerine müellifin verdiği olumsuz cevap karşılığında dövülmesi ve mescitten çıkarılarak teşeyyu ile suçlanması ve daha sonra Remle denilen yerde ölmesi bunlardan biridir. Zaten Tüsterî de bu bilgileri nakletmeden evvel bizzat İbn Hallikân'ın ismini zikretmektedir. Fakat görebildiğimiz kadarıyla Tüsterî’nin bu

65 Kutluay, Imâmiyye Şîsı'na Göre Cerh ve Ta'dîl, 145.

66 Mesela bkz. et-Tûsî, Ebû Cafer Muhammed b. Hasan b. Ali, el-Fihrist, nşr. Eş-Şerîf er-Rızâ, Necef, ts., s. 36; Erdebîlî, Muhammed b. Ali el-Karavî el-Hâirî, Câmiu'r-ruvât ve îzâhâtü'liştibâhât anit-turuk ve'-isnâd, İran, 1403, I, 51; Mâmekânî, Abdullah b. Muhammed, Tenkîhu'l-makâl fî ilmi'r-ricâl, (I-XXIV), thk. Muhyiddîn el-Mâmekânî, Kum, 1423/1983, VI, 175; en-Nâmâzî, el-Hâc Ali, Müstedrekâtü ilmi ricâli'I-hadîs, (I-VIII), Müessesetü'n-neşri'lİslâmî, byy. 1426, I, 328; Hûî, Ayetullah Ebu'l-Kâsım b. Ali Ekber b. Haşim el-Mûsevî, Mu'cemü ricâli'l-hadîs ve tafsîli tabakâti'r-rüvât, Müessesetü'l- İmâm el-Hûî el-İslâmiyye, Necef, ts., II, 134; et-Tüsterî, Muhammed Takî, Kâmûsü'r-ricâl, (I-XII), Müessesetü'n-neşri'lİslâmî, byy., 1431, I, 478.

67 Bkz. Mâmekânî, Tenkîhu'l-makâl, VI, 175. 
eserinde Nesâî'ye mezhepsel olarak bir sahiplenme belirtisi de bulunmamaktadır. ${ }^{68}$

Hem Ehl-i Sünnet hem de Şîa ricâl edebiyatında yer alan Nesâî'nin biyografisine bakıldığında onun teşeyyu ile suçlanmasına neden olan birbirine benzer birkaç olaydan başka tatmin edici bilginin bulunmadığı görülecektir. Tabii ki yukarıda da vurgulandığı gibi Nesâî’nin Şiîlikle suçlanmasına sebep olan olayların asıl yer aldığı kaynak Ehl-i Sünnet çizgisinde yer alan ricâl edebiyatıdır. Bu konuda Şîa'nın ilk dönem kaynaklarında müellifin Şiîliğiyle ilgili her hangi bir bilgi bulunmamaktadır. Ayrıca bu mezhep çizgisinde kaleme alınmış ricâl edebiyatı içinde yer alan bilgilerde; Hz. Ali sevgisi, Muâviye'ye olan bakışı ve teşeyyu ile ilgili diğer bazı karineler esas alınarak Şîa mensubu muhaddislerin Nesâî’yi sahiplenmedikleri de anlaşılacaktır. Bu konuda Ehl-i Sünnet ekolü içinde yer alan kaynaklarda ise onun teşeyyu ile suçlanmasına neden olan olayların neredeyse olduğu gibi aktarımı yapılmış fakat müellifi Şiîlikle suçlayıcı ifade ve beyanlardan ise kaçınılmıştır.

\section{Sonuç}

Başta Hz. Ali'nin faziletine dair kaleme aldığı Hasâis adlı eseri ve $\mathrm{Hz}$. Muâviye hakkında kendisine nispet edilen olumsuz görüş ve değerlendirmeleri Nesâî'nin Şiîlikle suçlanmasının temel sebeplerindendir. Fakat diğer bütün deliller ortaya konduğunda bu suçlamanın haklı gerekçelere dayanmadığı anlaşılmaktadır. Çünkü öncelikle belirtmek gerekir ki tarihi süreçte Şiîlik alameti olarak da görülen Hz. Ali ve Ehl-i Beyt'e duyulan aşırı sevgi Kerbela gibi olayları gündeme getirip $\mathrm{Hz}$. Hüseyin'e duyulan üzüntü ve bunları yansıtan eserler kaleme almak sadece Nesâî'ye has bir durum değildir. Mahiyeti itibariyle efdâliyyet olarak da görülen; sevgi ve saygının ifadesi olan bu tür davranışların, aslında Sünnî olarak tanınan birçok ilim adamınca icra edilmiş bir tutum olduğu bilinen bir husustur. Ayrıca Nesâînnin Hz. Ali'nin faziletleriyle ilgili kaleme aldığı esere karşın diğer üç halifeyle birlikte Şiâ'nın eleştirdiği sahabeyi de içeren Fedâil adlı bir eser kaleme alması, Muâviye'yi öven sözler söylemesi kendisine yöneltilen teşeyyu suçlamasını boşa çıkaran en önemli delillerden kabul edilebilir.

68 et-Tüsterî, Kâmûsü'r-ricâl, I, 528, 529.

ÇÜiFD, 2018, cilt: 18, sayı: 1, ss. 167-191 
Nesâî'ye yöneltilen ve temeli $\mathrm{Hz}$. Ali sevgisi başta olmak üzere Muâviye ile ilgili söylediği birkaç olumsuz söze dayanan teşeyyu ithamı aslında devrin klasik özelliklerinden biridir. Genelde satır arası bilgilerden yola çıkılarak ileri sürülen bu iddiaların daha sonra Sünnî ve Şiî câmia tarafından kabul görmediği apaçık ortadır. Çünkü bütün bu iddialara rağmen Nesâî başta, kaleme aldığı Sünen'i olmak üzere diğer eserleri ve görüşleriyle Sünnî çizgide bulunan muhaddis ve diğer ilim adamlarının referans olarak kabul ettiği bir otorite olmuştur. Buna ilaveten klasik kaynaklarda Şiî olan muhaddis ve âlimlerce Nesâî'nin kendi mezhepleri çizgisinde bulunduğunu iddia ve ima eden her hangi bir bilgiye de rastlanmamıştır. Özellikle Şiî rical kitaplarında Nesâî'nin biyografisinin birkaç satırlık bilgiyle geçiştirilmiş olması ve onun mezhep ve itikadından neredeyse hiç bahsedilmemesi önemli bir husustur. Dikkate değer diğer bir husus ise onun Şiî oluşuyla ilgili iddiaların hemen hepsinin Sünnî kaynaklarda yer almasıdır. Kanaatimizce bu iddiaların temel sebeplerinden bazıları yukarıda bahsedilen satır aralarından seçilmiş bilgilere dayanan yanlış değerlendirme ve yorumlardır.

Ayrıca Nesâî'nin yaşadığı dönemde siyasî ve sosyal olaylar buna ilaveten bölgeye hâkim olan unsurlar sadece onun için değil diğer birçok muhaddis ve âlim hakkında yapılacak değerlendirme ve yorumlarda göz ardı edilmemesi gereken bir durumdur. Zira Nesâînin yaşadığı asırda başta Dımeşk, Nîsâbûr, Horasan ve Mâverâünnehir bölgelerinde farklı dinî ve fikrî düşüncelerin mücadelesi ile aynı din içerisinde değişik mezhep ve fırkaların faaliyetlerini görmek mümkündür. İşte zaman zaman bu farklı gruplar kendi fikirlerini destekleme maksadıyla referansından yararlanmayı planladığı bazı âlimleri baskı altında almış kendi görüşleri doğrultusunda fikirlerini bu âlimlere söyletmeye çalışmışlardır. Bölgeye hâkim olan gücün hızlı bir şekilde değiştiği, mezhepsel faaliyet ve mücadelelerin devam ettiği bu dönemde Nesâî'nin her ne kadar bu faaliyet, mücadele ve tartışmalardan uzak durduğu görülse de kendini bunlardan tamamen soyutlayamamış olması muhtemeldir. Çünkü kimi zaman çatışma halindeki iki farklı görüşten birini tercih etmemek dahi, bitaraf olmaktan ziyade taraf olmak şeklinde algılanmıştır. Bu çerçevede Nesâî'nin uzlaştırmacı bir niyet ve düşünceyle sergilediği duruşu yanlış anlaşılmış olabilir. Çünkü yaşadığı coğrafi bölge ve asrın özellikleri Nesâînnin de bu tür uygulamaya maruz kalmış olabileceğini göstermektedir. 
Ortaya attığı görüş ve düşünceleri, yazmış olduğu eserleri bakımından Sünnî ekol içinde tebârüz etmiş bazı muhaddislerin/âlimlerin kimi zaman bir veya birkaç eseri yahut ayrıntı mahiyetindeki bir sözünden dolayı başta Şiîlikte suçlandığı daha sonra onun hakkındaki bu ithamların Râfizîlik derecesine kadar götürüldüğü bilinmektedir. Oysaki Nesâî, ulaşabildiğimiz kaynakların hiçbirinde aşırı Şiî olmayı ifade eden Râfizilikle itham edilmemiştir. Nesâî'nin ağır bir şekilde Şiîlikle itham edilmeyişinin en önemli nedenlerinden biri teşeyyu ile suçlanmasına sebep teşkil eden eser, görüş ve düşüncelerinin mezhebî bir boyut kazanmamış, aksine entelektüel düzeyde seyretmiş olmasından kaynaklanmış olabilir.

Öte yandan Nesâî'nin Şiîlikle ithamında aleyhine olabilecek delilleri önceleyerek lehine olanları görmezden gelmek objektif bir bakış açısını yansıtmamaktadır. Çünkü kaynaklarda onun Şiî oluşuyla ilgili aleyhinde kullanılan her bir delil için karşı bir delilin de olduğu ortadadır. Bunlardan biri Hz. Ali için kaleme aldığı Hasâis adlı eseridir ki buna karşın diğer üç halifeyi de kapsayan ve Şiî câmia tarafından olumsuz bakılan sahabeden bazılarını da içine alan Fedâil adlı eserini kaleme almıştır. Bunun yanında Muâviye aleyhine söylediği iddia edilen sözler de suçlanma nedenlerinden biridir ki, kaynaklarda bu sahabî hakkında aynı zamanda övgü niteliği taşıyan sözlerinin olması bu delilin boşa çıktığı yönünde değerlendirilebilir.

Zikredilen tüm bu bilgi ve deliller bütüncül bir bakış açısıyla değerlendirildiğinde aslında Nesâî'nin takip ettiği metotla Ehl-i Sünnet ve Şiâ arasında devam eden mücadelelere karşı bilinçli bir denge politikası ortaya koymaya çalıştığı anlaşılmaktadır. Şiîlikle suçlanmasının temel sebeplerinden olan Muâviye hakkındaki görüşleri ve bu nedenle dövülmesi, Dımeşk'te Hz. Ali'ye karşı olan soğukluğu yazdığı eseriyle giderme gayreti buna ilaveten Şiîlerin husumet beslediği halifeleri de içine alan bir eser kaleme alması bu çabanın göstergelerinden bazılarıdır. Nesâî'nin söz konusu olayları yaşadığı zaman diliminde Dımeşk ve çevresine hâkim olan gücün Sünnî ağırıklı olması fakat hem devlet yönetiminde hem de sosyal çevrede Şiî etkisinin de devam etmesi zikredilen denge politikası iddiamızı desteklemektedir. Bütün bunlara karşı Nesâî için en büyük talihsizlik, uzlaştırmacı bir niyetle kaleme aldığı iki farklı eserden sadece Hz. Ali lehindeki sözlerinin dikkate alınmış olması buna karşılık Muâviye lehine söylemiş olduğu sözlerin görmezden gelinmesi olmuştur. 


\section{Kaynakça}

Aslan, Hasan, Hadis Literatüründe Fedâilü'sahâbe Türü Kaynaklar ve Nesâî'nin "Fedâilü's-sahâbe'si", Şırnak Üniversitesi Sosyal Bilimler Enstitüsü, Basılmamış Yüksek Lisans Tezi, Şırnak, 2017.

Ateş, Ali Osman, Ehl-i Sünnet ve Şîa'nın Delil Aldığı Bazı Hadisler, Beyan Yayınları, İstanbul, 1996.

Aydınlı, Abdullah, "Şîa'da Hadis”, Hadîs Yazıları, İstanbul, 2014, s. 223-234.

Büyükkara, Mehmet Ali, "İmâmiyye Şia'sının Hadis Usûlünde Mezhebi Bozuk Raviler (I-)", İslâmî Araştırmalar Dergisi, 2004, XVII, sy 3, s. 201-215. , "İmâmiyye Şia'sının Hadis Usûlünde Mezhebi Bozuk Raviler (II-)", Isslâmî Araştırmalar Dergisi, 2004, XVII, sy 4, s. 354-368.

Çolak, Ahmet, Şia Hadis Alma Usulünde Illk Raviler, Basılmamış Yüksek Lisans Tezi, Erzurum Atatürk Üniversitesi Sosyal Bilimler Enstitüsü, Erzurum, 1993.

Demirci, Kadir, Zeydiyye'nin Hadis Anlayışı, Basılmamış Doktora Tezi, Ankara Üniversitesi Sosyal Bilimler Enstitüsü, Ankara, 2005.

------------------, Ehl-i Sünnet IIle Imâmiye Şiası Arası Karşılaştırmalı Hadis İlimleri, Karınca Polen Yayınları, İstanbul, 2014.

Erdebîlî, Muhammed b. Ali el-Karavî el-Hâirî, Câmiu'r-ruvât ve îzâhâtü'l- iştibâhât ani't-turuk ve'l-isnâd, İran, 1403.

Eren, Mehmet, Şîa'da Hadis Ricâli IIImi Kaynakları ve Konuları, Konya, 2010.

Evgin, Abdulkadir, "Hanefî ve Ca'ferîlerin Hadis Anlayışlarına Karşılaştırmalı Bir Bakış", Imâm-ı Azam Ebû Hanîfe ve Düşünce Sistemi (Sempozyum Tebliğ ve Müzakereleri), I-II, Bursa, 2005, I, s. 435-439.

, "Caferî İnanç Sisteminde Hadîs Anlayışı", Din Bilimleri Akademik Dergisi, 2004, IV, sy. 1, s. 117-147.

Hûî, Ayetullah Ebu'l-Kâsım b. Ali Ekber b. Haşim el-Mûsevî, Mu'cemü ricâli'lhadîs ve tafsîli tabakâti'r-rüvât, Müessesetü'l- İmâm el-Hûî elİslâmiyye, Necef, ts.

İbn Asâkir, Ebu'l-Kâsım Ali b. Hasan b. Hibetullah, Târîhu Dımeşk, (I-LXXX), thk. Amr b. Garâme el- Umrevî, Dâru'l-Fikr, 1995.

İbn Hacer el-Askalâni, Ebu'l-Fadl Ahmed b. Ali b. Muhammed b. Ahmed, Mîzânü'l-l'tidâl fî nakdi'r-ricâl, (I-IV), Ali Muhammed el-Becâvî, Dâru'lma'rife, Beyrût, 1963. 
İbnu'l-Cevzî, Cemalüddîn Ebu'l-Ferec Abdurrahman b. Ali b. Muhammed, elMuntazam fî târîhi'l-umemi ve'l-mulûk, (I-XIX), thk. Muhammed Abdulkadir Atâ/Mustafa Abdulkadir Atâ, Dâru'l-kütübi'l-ilmiyye, Beyrût, 1992.

İbnu'l-İmâd, Ebü'l-Felâh Abdülhay b. Ahmed b. Muhammed es-Sâlihî elHanbelî, Şezerâtu'z-zeheb fî ahbâri men zeheb, (I-XI), thk. Mahmûd el-Arnaûd, Dâru İbn Kesîr, Dımeşk/Beyrut, 1986.

Kandemir, M. Yaşar, "Hadis/Şîa ve Hadîs", DIA, XV, 38-40. , "Nesâî", DIA, XXII, 564.

Karahan, Abdullah, “Şîa'nın Dört Muteber Ricâl Kitabı”, Marife, yıl. 8, sayı. 3, kış 2008, ss. 309-329.

Kutlu, Cahit, Şîa'nın Hadis Vaz'ındaki Rolü, Yüksek Lisans Tezi, Ankara Üniversitesi Sosyal Bilimler Enstitüsü, Ankara, 1995.

Kutluay, İbrahim, "İmâmiyye Şîası'na Göre Haber-i Vâhidin Hücciyeti Problemi-Şeyhü’t-Tâife et-Tûsî Özelinde-", Marife, 2014, XIV, sy.2, s. 63-84. İstanbul, 2012.

, Imâmiyye Şîası'na Göre Cerh ve Ta'dîl, Rağbet Yayınları,

Kuzudişli, Bekir, Şîa ve Hadis, Klasik, İstanbul, 2017.

Mahmut Şakir, Hz. Adem'den Bugüne İslam Tarihi, (çev. Ferit Aydın), Kahraman Yayınları, İstanbul, 2004.

Mâmekânî, Abdullah b. Muhammed, Tenkîhu'l-makâl fî ilmi'r-ricâl, (I-XXIV), thk. Muhyiddîn el-Mâmekânî, Kum, 1423/1983.

en-Nâmâzî, el-Hâc Ali, Müstedrekâtü ilmi ricâli'l-hadîs, (I-VIII), Müessesetü'nneşri'l- İslâmî, byy. 1426, I, 328.

Nesâî, Ebû Abdurrahmân Ahmed b. Şuayb b. Alî, Hasâisu emîri'l-mü'minîn Ali b. Ebî Tâlib radıyallahu anh, Ahmed Mîrîn el-Belûşî, Kuveyt, $1406 / 1986$.

Oğur, Necmettin, Şîa'da Ricâl İlminin Gelişimi ve Bu Alanda Yapılan Çalışmalar, Yüksek Lisans Tezi, Marmara Üniversitesi Sosyal Bilimler Enstitüsü, İstanbul, 2002.

Önal, Recep, “Mâtürîdî'nin Hayatı, Eserleri ve Kelam İlmi'ndeki Yeri”, Akademik Incelemeler Dergisi, 8, 3 (2013), ss. 325-360.

, Ebü'l-Berekât en-Nesefî ve Kelamî Polemikleri, Emin Yay., Bursa, 2017, s. 366-374. 
Robson, James, Sünen-i İbn Mâce'nin (Nüshalarının) Rivâyeti, çev. Musa Erkaya, Dinî Araştırmalar, 2005, cilt: VIII, sayı: 23, s. 287-298.

Sofuoğlu, M. Cemal, Şîa'nın Hadis Anlayışı, Doktora Tezi, Ankara Üniversitesi İlahiyat Fakültesi, Ankara, 1977.

, Hadis Tenkidi Yönünden el-Kâfî Üzerine Bir Deneme, Ankara Üniversitesi İlahiyat Fakültesi Yayınları, Ankara, 1982.

Tokpınar, Mirza, “Abdurrezzak b. Hemmâm'ın Şiilikle İtham Edilmesi Üzerine Bir İnceleme (I-)", Dini Araştırmalar, 2001, IV, sy 9, s. 77-92.

, "Abdurrezzak b. Hemmâm'ın Şiilikle İtham Edilmesi Üzerine Bir İnceleme (II-)”, Dini Araştırmalar, 2001, IV, sy 10, s. 71-88.

et-Tûsî, Ebû Cafer Muhammed b. Hasan b. Ali, el-Fihrist, nşr. eş-Şerîf erRızâ, Necef, ts.

et-Tüsterî, Muhammed Takî, Kâmûsü'r-ricâl, (I-XII), Müessesetü'n-neşri'lİslâmî, byy., 1431, I, 478.

Uyar, Mazlum, Imâmiyye Şîası'nda Ahbârîlik, Doktora Tezi, Dokuz Eylül Üniversitesi Sosyal Bilimler Enstitüsü, İzmir, 1996.

Ünalan, Abdullah, Şia'da Hadis Usûlü, İşrak Yayınları, İstanbul, 2008.

, Ehl-i Sünnet ve Şîa'nın Imamette Dayandığı Hadisler, Doktora Tezi, Harran Üniversitesi Sosyal Bilimler Enstitüsü, Şanlıurfa, 1998.

Yavuz, Adil, "Kisâ Hadisi Rivâyetleri ve Ehl-i Beyt Kimliği”, Selçuk Üniversitesi İlahiyat Fakültesi Dergisi, 2005, sy. 19, s. 153-177.

Yıldırım, Enbiya, "el-Hâkim en-Neysâbûrî̀nin Şiîlikle İtham Edilmesi”, Ankara Üniversitesi Illahiyat Fakültesi Dergisi, 57:1 (2016), ss.57-84.

Yıldız, Hakkı Dursun, "Abbâsîler”, DiA, I, 31-48.

Yücesoy, Hayrettin, "Mihne”, DIA, XXX, 26-28.

Zehebî, Şemsüddîn Ebû Abdullah Muhammed b. Ahmed b. Osman b. Kaymâz, el-liber fî haberi men gaber, (I-IV), thk. Ebû Hâcir Muhammed es-Saîd, Dâru'l-kütübi'l-ilmiyye, Beyrut, ts.

, Mîzânu'l-i'tidâl fî nakdi'r-ricâl, (I-IV), thk. Ali Muhammed elBecavî, Dâru'l-marife, Beyrût, 1963.

1998.

Tezkiratü'l-huffâz, (I-IV), Dâru'I-kütübi'I-ilmiyye, Beyrût, Siyeru a'lâmi'n-nübelâ, (I-XL), Dâru'I-hadîs, Kahire, 2006. 


\section{To be Accused with Shiism of Al-Nasa'i (303/915)}

Citation / (-) Aba, V. (2018). To be Accused with Shiism of AlNasa'i (303/915), Çukurova University Journal of Faculty of Divinity, 18 (1), 167-191.

Abstract- Hadiths, narrators and the books are examined by their experts according to some criteria from various perspectives. According to the result of this technical examination, a certain provision is given. Hence, different views can be come up about a narrator in the historical process. Whether these views are real or not can sometimes not be detected exactly, and a narrator faced with an unjustified accusation. In the context of the AlJarh wa at-Tadil criterion, sometimes different materials can be put forward about criticism of narrators. One of these is the accusation of narrator with Shiism. Nasai who wrote a number of works especially Sunan in the field of hadith, has been accused with Shiism too. Although such accusations about Nasai are found in various sources, they are not based on solid evidence. The accusations in questions, however, made him a matter of debate, such accusations in the later period caused him to come to the agenda. Therefore, Nasai, who is the authority of the hadith by all means, was attracted to the attention due to his qualification that is the cause of criticism. In this study, the validity of the information on which the aforementioned allegations are based and the validity of the evidences is examined. Thus, it is tried to be revealed to what extent Nesai's accusation with Shiism is correct. It is understood that when the information and evidence that are put forward are evaluated from a holistic point of view, Nasai, with the method that he follows, try to put forth a conscious balance policy against the continuing struggles between the two groups.

Keywords- al-Nasai, The accusation of Shiism, Jarh, Sunni, Rafidi, Ali, Muawiya 